\title{
Improving Compliance in the Russian Foreign Exchange Market
}

\author{
Shihao Yang \\ Ealing International School, Dalian, Liaoning Province, 116021, China \\ Corresponding author's e-mail: angela@cas-harbour.org
}

\begin{abstract}
Since the Central Bank of Russian Federation, the only regulator of the foreign exchange industry in Russia, took over the Russian foreign exchange market, its style is regarded as very strict, strong, or even authoritarian. As a result, even licensed brokers guide customers to use offshore supervision. To address the substantial cheating even with heavy oversight, which leads to the studies of human failures in terms of psychology and behavioral finance integrated with morality, a highly completed financial education of risk management is required. Since the financial market and institutions are created only for the purpose of humans' welfare, the elementary mission of the democratization of finance raised by Robert. J. Shiller is developing some ultimate objectives for all humans, which implies that behavioral finance, defined as the human sciences applied on finance, will eventually take the main thrust of financial studies into political philosophy, following the path of policy-making exploration, of human satisfaction, of freedom, of the love of sublime.
\end{abstract}

Keywords: behavioral finance, market regulation, the Central Bank of Russian Federation, foreign exchange, political philosophy

\section{INTRODUCTION}

In Russia, due to the existence of the supervisory holes, there is a lack of corresponding laws and regulations to support both the dealing with complaints from traders and recovering funds from traders. In order to improve compliance in the Russian foreign exchange market, the following topics will be discussed. Firstly, the reason why developed markets have created a mild regulatory oversight environment with a small amount of cheating, while the Russian system is strictly monitored, there is still a large amount of fraud. Secondly, the actions taken by the Central Bank of the Russian Federation to address this discrepancy and the reasons for its failure. Thirdly, from the perspective of psychology, some human errors with a significant impact on the financial market will be directly applied in foreign exchange transactions. Based on the studies above, suggestions about what Putin needs to do to achieve this goal will be raised. Besides, the future direction of behavioral finance associated with social sciences will be predicted.

\section{THE CENTRAL BANK OF RUSSIAN FEDERATION}

In 2012, the number of newly established brokers in Russia increased rapidly [1]. In November 2013, the Central Bank of Russian Federation announced the dissolution of Mega regulator, the only financial regulator in the country, which had been supervising financial activities including foreign exchange [2]. Meanwhile, the Russian authorities began to take a very negative attitude towards the retailing foreign exchange industry. However, at the same time, Russia was dealing with the Ukrainian revolution and the subsequent financial crisis in Russia, which delayed the regulatory actions of the Russian authorities on the foreign exchange industry.

In a draft published by The Central Bank of Russia in June 2015, all Russian foreign exchange brokers must become foreign exchange self-regulatory organizations[3].Each member needed to pay a total entrance fee of RUB 2 million (USD 35,629). If a foreign exchange broker goes bankrupt, the compensation fund would first accept an application from the broker's client and then create a special register of payments of compensation. According to the law, any clients of an insolvency broker can apply for a fund compensation which requires a paper-based process [4].

On October 1, 2015, the Central Bank of Russian Federation officially became the country's foreign exchange regulator [5]. As soon as The Central Bank of Russian Federation took over, strict regulations on leverage had been introduced, allowing brokers to provide leverages only below 50: 1 , and the leverage ratio continued to decline[6]. The companies licensed by the Central Bank of Russian Federation could only conduct businesses as foreign exchange dealers. The time for approval of foreign exchange licenses is 2 months. The minimum registered capital requirement for Russian foreign exchange licenses for applicants was RUB 100 million (USD 1.5 million). As part of a proper candidate assessment, executives, directors and shareholders must submit academic credentials and professional 
qualifications, industry experience and no criminal record. Companies must submit more than 40 documents required to obtain a permit, which includes surveys, references and business plans for the next two years[7]. The Central Bank of Russian Federation also asked foreign exchange companies which are not members of the Russian foreign exchange industry self-regulatory organization (FX SRO) to withdraw from the Russian foreign exchange market on January 1, 2016[8]. On January 1, 2016, due to the strong claim of the Russian Ministry of Finance and The Central Bank of Russian Federation, the Russian legislature introduced a new foreign exchange supervision bill which included foreign exchange transactions as high-risk transactions which requires strict supervision[9].

The non-cooperative game between the Central Bank of $\mathrm{R}$ ussian Federation and brokers has never stopped. Until Ap ril 2017, The Central Bank of Russian Federation has issu ed a total of only eight foreign exchange licenses. The bro kers who had obtained these eight licenses were ALAPAR I, FINAM FOREX, FOREXCLUB, INSTAFOREX, TEL ETRADE, TRUSTFOREX, VTB 24 and PROMSYYAZB ANK, which were all considered strong [10]. At the same time, many companies were refused to issue licenses by $\mathrm{T}$ he Central Bank of Russia, but the Central Bank of Russi an Federation did not either explain the reasons for the ref usal or provide any guidance on the adjustment. From Apr il 2017 until December 2018, The Central Bank of Russia $\mathrm{n}$ Federation did not issue any new foreign exchange licen ses. However, on December 27, which was only a few day $\mathrm{s}$ later, The Central Bank of Russian Federation revoked $t$ he licenses of all non-bank branches (ALAPARI, FOREX CLUB, TELETRADE, Fix Trade and TRUSTFOREX). T he Association of Traders also stated that it would suspen $\mathrm{d}$ membership of the five brokers on December 28. The C entral Bank of Russian Federation explained the action as they had violated regulatory requirements such as their ag gressive publicity methods and guided customers to the of fshore market [11].

During 2017, the Central Bank of Russian Federation blocked 400 websites, many of them were unlicensed foreign exchange brokers [12]. The Central Bank of Russian Federation stated that if unlicensed brokers provide services to customers, their websites would be recorded in a special monitoring system and blocked, even most regulatory agencies only issued platform warnings and the websites of the organizations that were warned can still operate normally[13].In addition, the Russian Federal Antimonopoly Service (FAS), who was responsible for conducting regulatory oversights over the legal protection of financial markets[14], banned the advertising of services of foreign exchange dealers whose licenses had been canceled and claimed that unlicensed brokers publishing promotional advertisements were in violation of Russian advertising law, which may lead to high fines[15].

In late October 2018, Russian regulators stated that they were considering a 30: 1 leverage limit. In addition, the new leverage limit may require professional training for foreign exchange brokerage clients [16]. The exact content of such training and whether it became a legal requirement was unclear. The Central Bank of Russian Federation only issued one license to Alfa FOREX (Moscow) on December 20, 2018[17].

Currently, hundreds of undocumented companies in the Russian foreign exchange market are providing services to Russian customers, and most of Russian customers are using offshore brokers. As mentioned above, even licensed brokers would guide customers to use offshore supervision, which has deepened the negative perception of The Central Bank of Russian Federation towards the foreign exchange industry. In conclusion, these regulations have highly affected the expansion of foreign exchange market as well as households' investment.

\section{HUMAN FAILINGS}

Still, the market regulation is considered necessary due to a variety of human failings. Firstly, people tend to believe what they want to believe [18].For instance, people tend to believe that the football team they support will win, which could be linked to a fanatical patriot of Russia. Some Russian people may invest a lot on Roubles, expecting it will become stronger, simply out of their willingness of Rouble becoming stronger. As a result, they can only see the pros of investing Rouble but ignore the cons, which lead to non-profitable decisions.

Secondly, people tend to be anchored by numbers while making quantitative judgments. Kahneman and Tversky, two behavioral economist who published the prospect theory, demonstrated the human failing through the Wheel of Fortune experiment in 1974. Generally they gave people questions which the answers are numbers from 0 to 100 , after rotating the fortune wheel to stop at one number, which was obviously out of randomness. In the experiment, people tend to choose a number which is close to the number shown on the wheel, and then strongly deny its influence[19]. As people are subconsciously influenced by recent numbers coming to the mind, all personally determined numbers in a foreign exchange trade can be affected by senseless impressions.

Thirdly, human attention is not always on the right track. People often pay too much attention to some things and too little to others, which has been proved by psychologists since more than a hundred years ago. For instance, with refers to classical herd behavior [20], people tend to pay attention to what other people are paying attention to so easily be convinced by an ordinary expert in finance who can possibly be believed by other people around them, which is even unrealistic in most cases, and promises that Roubles will become stronger or weaker on the newspaper just because other people seemed like believing that expert.

According to psychologist B.F.Skinner, magical thinking was firstly experimented on pigeons. He fed the pigeons completely at random, and after a while, he discovered that these pigeons have turned into "neuropathy". Some pigeons shook their heads in a specific direction, some kept turning their heads counter-clockwise and some kept dancing like they were hit by evil. Each pigeon has 
gradually developed its own conditioned reflex system, it seems that as long as it repeats an action, it will definitely get food. As the food was provided indeed, the behavior was further strengthened [21]. Another common example occurs when something good happens in the life of a religious person, which leads to theological reflection like, I get this because yesterday I did something which pleased the God. In terms of financial market, magical thinking frequently occurs when currency investors developed some trading strategy or asked certain Russian brokers that coincidentally do well, they start to consider themselves or the brokers they asked genius investors, which might not be true.

Furthermore, the term "quasi-magical thinking" was defined by two psychologist, whose names were Eldar Shamir and Amos Tversky [22].A Harvard psychologist, Ellen Langer, once conducted a coin-tossing experiment, which showed that people tend to bet more if they are allowed to guess the outcome before the coins are tossed [23]. Rationally, the probability distribution would be exactly the same whether the coin is tossed before or after the guessing. It concealed a illusion among people that they can control the randomness through their own willpower. As the price of a currency is always posterior, foreign exchange future traders may think that they can let the price go on the right way through their willpower, such overconfidence leads to multiple failures such as stopping the loss late or poor position management etc.

\section{CONCLUSION AND EXPECTATIONS}

According to the report of its consumer protection department, the Central Bank of Russian Federation received 246,600 complaints from customers of financial service providers in 2019, which was down $2.8 \%$ from 2018 levels. The number of complaints against foreign exchange brokers was only 40[24]. As the Central Bank of Russian Federation withdrew a variety of broker companies' foreign exchange license, the competition of Russian foreign exchange market was eliminated in about 2 years. However, a more accurate interpretation of the decline in the number of complaints is that the recent crackdown has been driving investors away from Russian licensed brokers and switched to the accounts in offshore jurisdictions.

The distinction between the financial markets of developed countries and the emerging markets in developing countries can be explained from two points of view. For one thing, in emerging markets of developing countries, individual investors with small funds play a major role in the market. The situation is completely different In developed countries where most of trades are conducted by financial institutions who are not willing to act against the law considering the worse consequence than the possible benefit gained. For another, according to Prospect Theory raised by D. Kahneman and A. Tversky [25], since people with less fortune tend to be more greed towards the fortune, which leads to tense pursuits of higher profits and the blind courage of taking the higher risk. As the financial education in developed countries is more thorough, the psychological effect is reduced to some extent, a greater proportion of the investors can evaluate the risk of illegal trading and keep calm.

In summary, a highly completed financial education of ris $\mathrm{k}$ management is what the developing countries need to ad dress the cheating even under heavy regulatory oversights. Further, as people with adequate financial education are more able to make profits in the market, with refers to the Prospect Theory mentioned before, profitability can reduc e people's over-risk-taking preference. Since the financial market and institutions are founded only for the purpose $o$ f humans' welfare, the elementary mission of the democra tization of finance is developing some ultimate objectives for all humans [26], which implies that behavioral finance, defined as the human sciences applied on finance, will ev entually take the main thrust of financial studies into politi cal philosophy, following the path of policy-making explo ration, of human satisfaction, of freedom.

"Who will educate the educators?", asked Karl Marx [27]. The answer is, to read old wisdom with the aspiration of an education in political responsibility [28]. The ancient Greeks call the desire for knowledge of the best regime "eros", or love. The political philosophy is one of the loftiest psalms we sing to the model of love, where people only giving, creating values for others and being loyal for their internal demand, denominated as the love of sublime.

\section{ACKNOWLEDGMENT}

First and foremost, I would like to show my deepest gratitude to Professor Ronald Leven and my tutors in the research group and my high school, who have provided me with valuable guidance in every stage of the writing of this thesis. Further, I would like to thank all my friends and beloved ones for their encouragement and support. Without all their enlightening instruction and impressive kindness, I could not have completed my thesis.

\section{REFERENCES}

[1] The Current Situation of Russian Forex Market after Withdrawing Licenses of Several Brokers, June 20, 2019. http://www.cngold.com.cn/hangye/20190620f12201n3 028186700.html

[2] Russian Forex Market is Facing a Supervisory Hole, December 5, 2013. http://www.financialnews.com.cn/wh/xw_110/201312/ t20131204_45851.html

[3] Annual report-2016, The Central Bank of the Russian Federation 
[19] R. J. Shiller. Human Behaviour and the Efficiency of the Financial System. Handbook of

Macroeconomics, 1999, vol. 1, part c.

[20] S. Bikhchandani, S. Sharma. Herd Behavior in Financial Markets: A Review. IMF Working Paper No. 00/48, March 2000.

[6] A. Saks-McLeod. Russia's Forex Law gets approved by the Federation Council, December 25, 2014. https://www.leaprate.com/news/russias-forexlaw-gets-approved-by-the-federation-council/

[7] Bank of Russia Licensing FX Brokers, December 28, 2018. https://55brokers.com/bank-of-russialicensing-fx-brokers/

[8] Annual report-2016, The Central Bank of the Russian Federation

[9] Global Forex Supervision: Russia, August 17, 2018. http://www.waihuibang.com/fxschool/beginner/39653. html

[10] M. Nikolova. Industry News, Retail FX, Week in Review, March 7, 2018, 1:02 pm UTC

[11] R. Joshi. Bank Of Russia Destroys Russian Retail Forex Market, December 31, 2018. https://www.tradersbible.com/news/forex/bank-ofrussia-destroys-russian-retail-forex-market

[12] M. Nikolova. Industry News, Retail FX, September 12, 2017, 3:50 pm UTC

[13] Annual report-2017, The Central Bank of the Russian Federation

[14] The Moscow OFAS Russia instituted proceedings against Yandex and Process-A LLC on grounds of violation of the Advertising Law, August 29, 2017. http://moscow.fas.gov.ru/news/15761

[15] M. Nikolova. Russian antimonopoly authorities target Yandex over illegal Forex advertising, Industry News, Retail FX, August 292017

[16] Regulators in Russia plan to cap the maximum FX leverage at 1:30, October 3, 2018.

https://theforexreview.com/2018/10/03/regulators-inrussia-plan-to-cap-the-maximum-fx-leverage-at-130/

[17] M. Nikolova, Industry News, Retail FX, December 20, 2018, 6:53pm UTC

[18] G. Mayraz. Wishful Thinking. Working paper, University of Oxford. 2013, vol. 36, no. 41, p. 1.
[21] B. F. Skinner. "Superstition" in the pigeon. Journal of Experimental Psychology, 2018, vol. 38, pp. 168172.

[22] E. Shafir, A. Tversky. Thinking through uncertainty: Nonconsequential reasoning and choice. Cognitive Psychology, 1992, vol. 24, no. 4, pp. 449474.

[23] E. J. Langer. "The Illusion of Control"', Journal of Personality and Social Psychology, 1975, vol. 32, pp. 311-328.

[24] M. Nikolova. Industry News, Retail FX, February 19, 2020, 7:49 pm UTC

[25] D. Kahneman, A. Tversky. 'Prospect Theory: An Analysis of Decision Under Risk,' Econometrica, 1979, vol. 47, pp. 263-291

[26] R. J. Shiller. Risk Management for Households. The Democratization of Finance. In: 6th BIS Annual Conference "Financial System and Macroeconomic Resilience”, Brunnen, June 19, 2007

[27] K. Marx. Theses on Feuerbach. 1845

[28] S. B. Smith, "In Defence of Politics", National Affairs (Spring 2011): 131-143 